\title{
Amphibians of the state of Piauí, Northeastern Brazil: a preliminary assessment
}

\author{
Igor Joventino Roberto ${ }^{1,4}$, Samuel Cardozo Ribeiro \& Daniel Loebmann $^{3}$ \\ ${ }^{1}$ Laboratório de Zoologia, Programa de Pós-graduação em Bioprospecção Molecular, Departamento de \\ Ciências Físicas e Biológicas, Universidade Regional do Cariri - URCA, \\ Rua Coronel Antônio Luiz Pimenta, 1161, CEP 63105-000, Crato, CE, Brasil \\ ${ }^{2}$ Programa de Pós-graduação em Ciências Biológicas (Zoologia), Departamento de Sistemática e \\ Ecologia, Universidade Federal da Paraíba - UFPB, Cidade Universitária, Campus I, \\ CEP 58059-900, João Pessoa, PB, Brasil \\ ${ }^{3}$ Laboratório de Vertebrados Ectotérmicos, Instituto de Ciências Biológicas, \\ Universidade Federal do Rio Grande - FURG, Av. Itália Km 8, Carreiros, \\ CEP 96203-900, Rio Grande, RS, Brasil \\ ${ }^{4}$ Corresponding author: Igor Joventino Roberto, e-mail: igorjoventino@yahoo.com.br
}

ROBERTO, I.J., RIBEIRO, S.C. \& LOEBMANN, D. Amphibians of the state of Piauí, Northeastern Brazil: a preliminary assessment. Biota Neotrop. 13(1): http://www.biotaneotropica.org.br/v13n1/en/abstract?invent ory+bn04113012013

\begin{abstract}
The state of Piauí is located between the Caatinga and Cerrado biomes in Northeastern Brazil, having a rich heterogeneity of habitats. However, publications regarding the amphibians of this state are scarce. We compiled literature data and complemented it with amphibian inventories in some municipalities of Piauí and present a list of 55 species (54 anurans and one caecilian). Ten of them are endemic to the Cerrado biome (Rhinella veredas, $R$. cerradensis, $R$. mirandaribeiroi, $R$. rubescens, Dendropsophus rubicundulus, Phyllomeduza azurea, Leptodactylus pustulatus, Eupemphix nattereri, Physalaemus centralis, and Proceratophrys goyana) and two endemic to the Caatinga (Rhinella jimi and Ceratophrys joazeirensis). We also present data about species richness of 18 sampled municipalities, species distribution patterns, and conservation status.
\end{abstract}

Keywords: Amphibia, Cerrado, Caatinga, distributional patterns, conservation.

ROBERTO, I. J., RIBEIRO, S.C. \& LOEBMANN, D. Anfíbios do estado do Piauí, Nordeste do Brasil: um ensaio preliminar. Biota Neotrop. 13(1): http://www.biotaneotropica.org.br/v13n1/pt/abstract?inventory+ bn04113012013

Resumo: O estado do Piauí está inserido nos Biomas Caatinga e Cerrado no nordeste do Brasil, ocasionando em uma rica heterogeneidade ambiental ao longo do seu território. Entretanto, estudos publicados sobre os anfíbios desse estado são escassos. Nós realizamos uma compilação de dados na literatura e complementamos com inventários faunísticos em algumas localidades do Piauí, e apresentamos uma lista de 55 espécies de anfíbios (54 anuros e uma cecília). Destas, dez espécies são endêmicas do Cerrado (Rhinella veredas, $R$. cerradensis, R. mirandaribeiroi, R. rubescens, Dendropsophus rubicundulus, Phyllomeduza azurea, Leptodactylus pustulatus, Eupemphix nattereri, Physalaemus centralis e Proceratophrys goyana) e duas endêmicas da Caatinga (Rhinella jimi e Ceratophrys joazeirensis). Apresentamos dados sobre a riqueza de anfíbios de 18 municípios amostrados do Estado e fazemos considerações sobre os padrões de distribuição das espécies e seu estado de conservação.

Palavras-chave: Amphibia, Cerrado, Caatinga, padrões de distribuição, conservação. 


\section{Introduction}

Amphibians are considered the most threatened animal group worldwide (Stuart et al. 2004). Over the past decades the increasing number of population declines and extinctions are alarming the scientific communities, especially due to the fact that these number are more than likely underestimated because of several undescribed taxa that could become extinct without ever being discovered (Young et al. 2001, Carnaval et al. 2009). In this context, the knowledge of species diversity and distribution and the determinant factors which lead to these biogeographic patterns are essential for conservation planning, providing effective tools in the identification of priority areas (Figueiredo et al. 2006).

The Brazilian territory is known for housing the highest amphibian diversity worldwide. According to Brazilian Society of Herpetology a total of 946 described species has been recognized to the country so far (Segalla et al. 2012). However, the vast degradation of natural habitats increases the extinction rates of populations at higher levels (Silvano \& Segalla 2005) and several regions remain unknown regarding the diversity of amphibian species and their distribution, especially in northeastern Brazil (Loebmann \& Haddad 2010). In this sense we provide the first assessment regarding amphibian diversity and biogeographic patterns in the state of Piauí, a region situated between the Cerrado and the Caatinga biomes in northeastern Brazil.

\section{Materials and Methods}

\section{Study area}

Located in an ecotonal area between the Cerrado and the Caatinga domains, the state of Piauí covers an area of 251,529 $\mathrm{km}^{2}$. Most areas of the state present low relief with elevations below 500 meters, but in the extreme southwest, on the border of the states of Tocantins, Maranhão and Bahia, mountainous areas reach up to 900 m (Figure 1). The main landscapes that are found in the state are: 1) Extensive areas of palm tree forests are found in patches. Three dominant species are found in these forests: Mauritia sp. L. f. (Buriti), Orbignya sp. Mart. ex Endl. (Babaçu) and Copernicia prunifera (Mill.) H.E. Moore (Carnaúba) (Liliopsida, Arecales, Arecaceae). However, due to their distinct physiological tolerances regarding soil moisture these species are not syntopic. 2) Cerrado formations comprise the widest natural areas covering the state of Piauí. These areas are predominantly composed by herbaceous, shrub or forested formations. 3) Caatinga formations can be found in areas from northeast of the state, associated with drier areas. 4) In the extreme north of the state a narrow strip of coastal zone form a complex mosaic of several habitats such as coastal dunes, rocky shores, mangrove forests, estuaries, and sandy beaches (see Loebmann et al. 2010a).

The main data for the elaboration of the amphibian list was gathered through literature research and inventory collections from various localities in Piauí. Data obtained from literature and their respective localities are available at Table 1 . Additionally we performed collections in three municipalities, Caxingó, Ribeiro Gonçalves and São Raimundo Nonato. To sampled amphibians in Ribeiro Gonçalves, we used two methodologies as follow: pitfall traps arrays, consisted of eleven 60-liter plastic buckets, arranged in a linear design, with a drift fence of 1.0 meter height; totalizing an effort of 231 pitfall traps/nights, and visual encounter survey, totalizing $36 \mathrm{man} /$ hour of effort. In the municipalities of Caxingó and São Raimundo Nonato our samples consisted of visual encounter

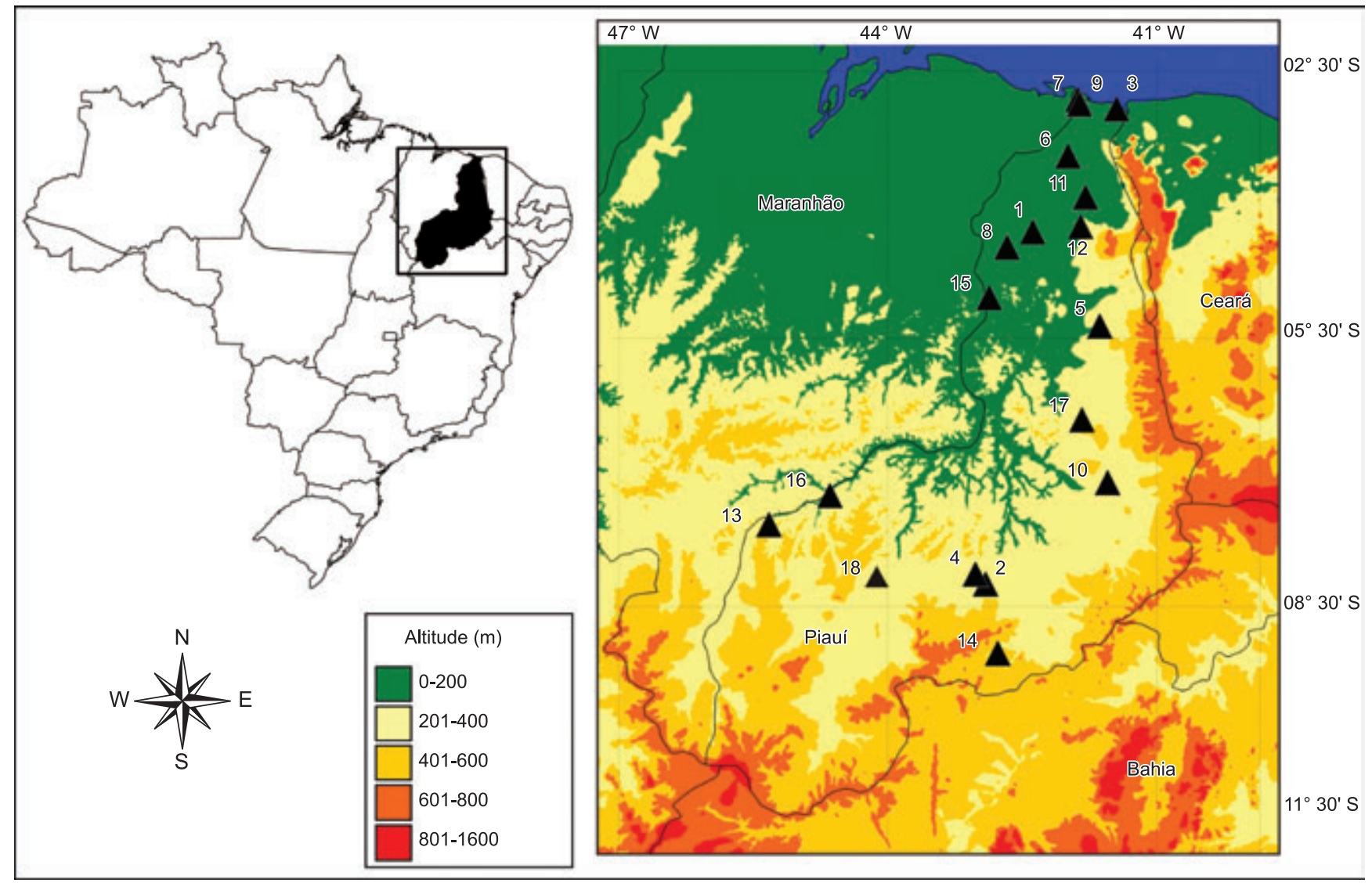

Figure 1. Map of State of Piauí showing the sampled localities: Municipalities of 1- Barras, 2- Brejo do Piauí; 3- Cajueiro da Praia; 4-Canto do Buriti; 5-Castelo do Piauí; 6-Caxingó; 7-Ilha Grande de Santa Isabel; 8-Lagoa Alegre; 9-Parnaíba; 10-Picos; 11-Piracuruca; 12-Piripiri; 13-Ribeiro Gonçalves; 14-São Raimundo Nonato; 15-Teresina; 16-Uruçuí; 17-Valença; 18 - Gurgueia. 
Roberto, I.J. et al.

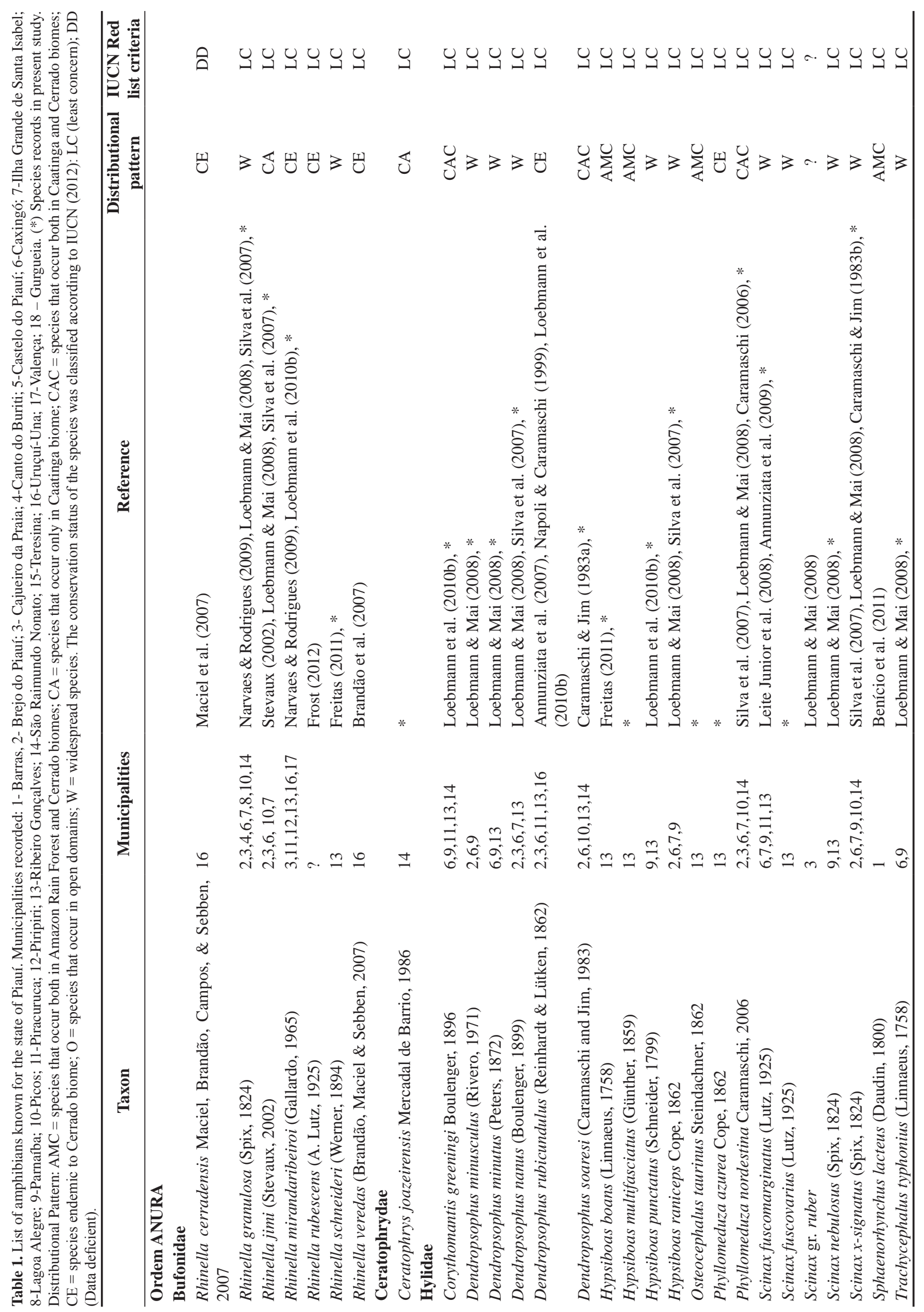


Amphibians of Piauí State

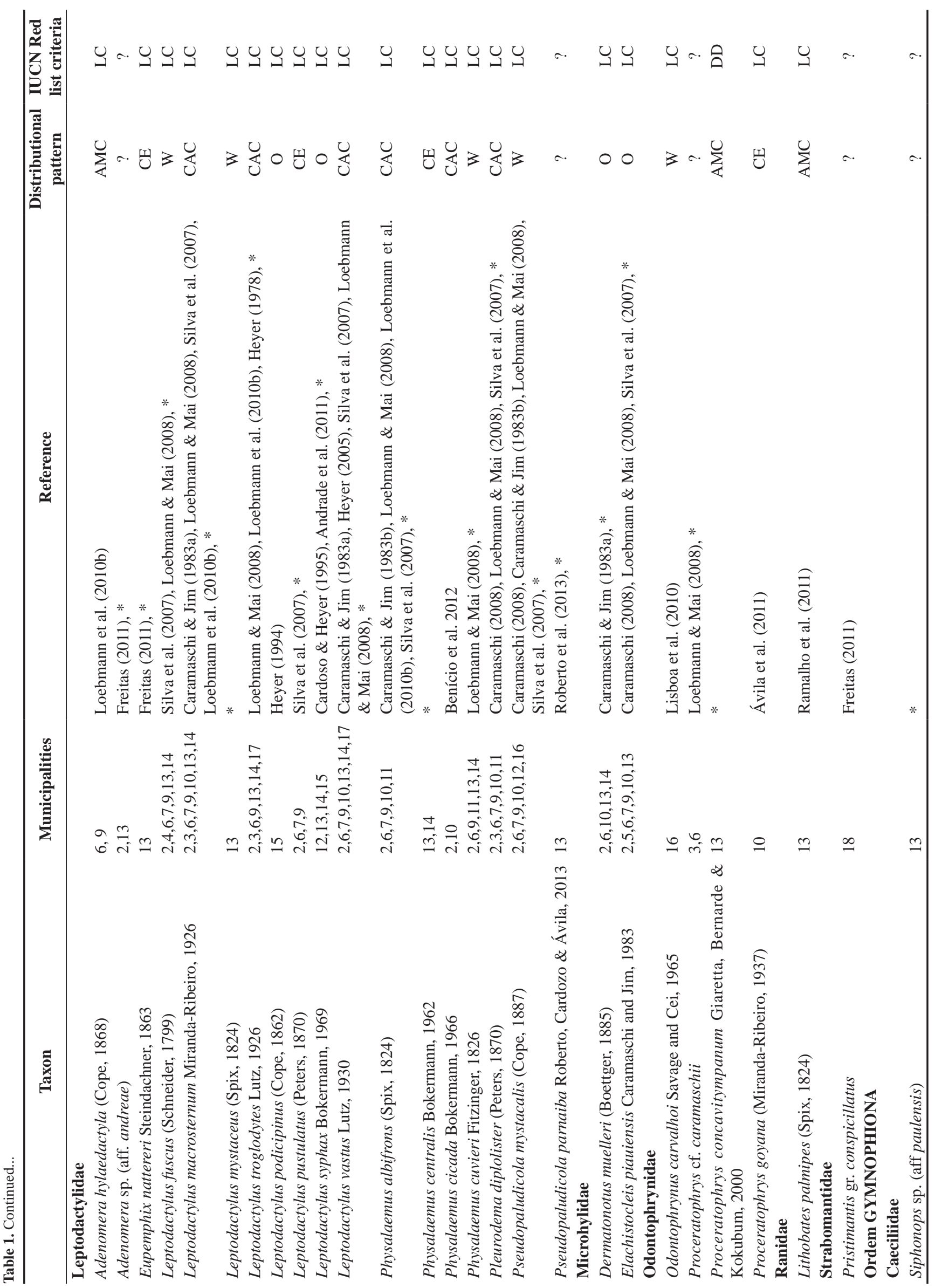


surveys only, with a total effort of 60 hours in Caxingó and 56 hours in São Raimundo Nonato. It is important to emphasize that sampling efforts were unequal among sites. Therefore, differences among species richness in each site should be carefully interpreted. Collection permits were issue by Instituto Chico Mendes de Conservação da Biodiversidade (ICMBio 26171-1, 4301-1, 36995-1).

Species distributional patterns as well as their association with the major Brazilian biomes were determined according to Valdujo et al. (2012) as following: AMC = species that occur both in the Amazon Rainforest and the Cerrado biomes; CA = species that occur only in the Caatinga biome; CAC = species that occur both in the Caatinga and the Cerrado biomes; $\mathrm{CE}$ = species endemic to the Cerrado biome; $\mathrm{O}=$ species that occur in open domains; $\mathrm{W}=$ widespread species. The conservation status of the species was classified according to the IUCN (2012). Taxonomic arrangement is as in Frost (2013).

\section{Results}

We recorded a total of 55 amphibian species in the state of Piauí from information available in the literature and from field collections carried out in this study (Table 1, Appendix 1), distributed in the orders Anura (54 species) and Gymnophiona (one species). Anurans were represented by seven families as follows: Bufonidae (seven species; one genus); Ceratophryidae (one species); Hylidae (20 species; eight genera); Leptodactylidae (18 species; six genus); Microhylidae (two species; two genera); Odontophrynidae (four species; two genus), Ranidae and Strabomantidae (both with one species). Gymnophiona was represented only by Siphonops sp. (aff. paulensis) (Caeciliidae). Among species recorded three are pontentially undescribed taxa: Adenomera sp. (aff andreae), Scinax gr. ruber and Siphonops sp. (aff. paulensis).

We registered 18 municipalities with at least one amphibian recorded (Figure 1), which represent $17.6 \%$ of the municipalities of Piauí $(n=224)$. Ribeiro Gonçalves ( $n=32,62 \%$ of the Piauí's species), Caxingó ( $n=26,52 \%)$, Brejo do Piauí ( $n=22,40 \%$ ), Parnaíba ( $\mathrm{n}=19,36 \%)$ and Ilha Grande de Santa Isabel $(\mathrm{n}=15$, $30 \%$ ) were the municipalities with highest number of recorded species (Figure 2).

Regarding the distributional patterns of species, we found 10 species endemic to the Cerrado biome (Rhinella veredas (Brandão, Maciel \& Sebben, 2007), R. cerradensis Maciel, Brandão,
Campos \& Sebben, 2007, Rhinella mirandaribeiroi (Gallardo, 1965), $R$. rubescens (A. Lutz, 1925), Dendropsophus rubicundulus (Reinhardt \& Lütken, 1862 “1861”), Phyllomeduza azurea Cope, 1862, Leptodactylus pustulatus (Peters, 1870), Eupemphix nattereri Steindachner, 1863, Physalaemus centralis Bokermann, 1962) and Proceratophrys goyana Miranda-Ribeiro, 1937; (fifteen species with widespread distribution; two endemic to the Caatinga biome, Rhinella jimi (Stevaux, 2002) and Ceratophrys joazeirensis Mercadal de Barrio, 1986); ten species occurring both in the Caatinga and the Cerrado biomes; four occuring in open domains (Caatinga, Cerrado, Pantanal) and six species occurring in the Cerrado and the Amazon Rainforest (Table 1; Figure 3).

According to the IUCN (2012) red list of threatened species, $85 \%(n=47)$ of the species that occurs in the Piauí were classified as Least Concern. Only Rhinella cerradensis and Proceratophrys concavitympanum are classified as Data Deficient. Adenomera sp. (aff. andreae), Proceratophrys cf. caramaschii, Pristimantis gr. conspicillatus, Pseudopaludicola parnaiba, Scinax gr. ruber, and Siphonops sp. (aff. paulensis) have no IUCN red list status so far.

\section{Discussion}

Caramaschi \& Jim (1983a, b) provide a preliminary list of amphibians from the municipality of Picos, Piauí, where 10 species were recorded, including two new species: Dendropsophus soaresi and Elachistocleis piauiensis, which were formally described by these authors. Rodrigues (2003) mentions the occurrence of three and eight amphibian species for the municipalities of Piripiri and Valença, respectively; however, species identification is not provided. Recent new research inventories, most of them along the coastal zone of Piauí (Silva et al. 2007, Loebmann \& Mai 2008, Loebmann et al. 2010b), increased the known amphibian fauna by 30 species. Recent new records of distribution such Lithobates palmipes (Ramalho et al. 2011), Odontophrynus carvalhoi (Lisboa et al. 2010), Sphaenorhynchus lacteus (Benício et al. 2011) and Physalaemus cicada (Benício et al. 2012) have also contributed to the increased knowledge of the amphibian fauna of the state.

Besides species presented in this article, Freitas (2011) reports the occurrence of Leptodactylus caatingae Heyer \& Juncá, 2003, Leptodactylus labyrinthicus (Spix, 1824), Leptodactylus sp., Physalaemus marmoratus (Reinhardt \& Lütken, 1862 “1861”), and

Amphibian richness - Piauí state

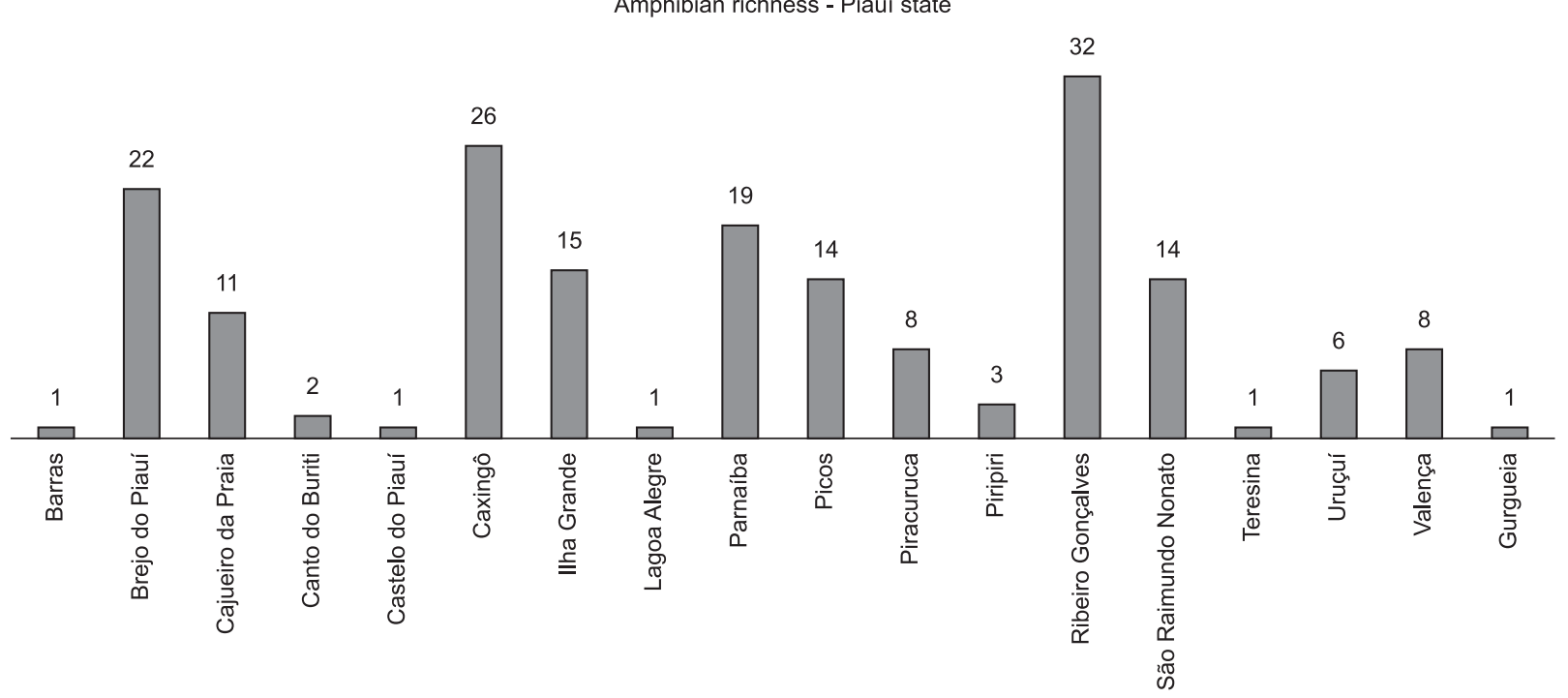

Figure 2. Amphibian richness for the municipalities of the State of Piauí. 


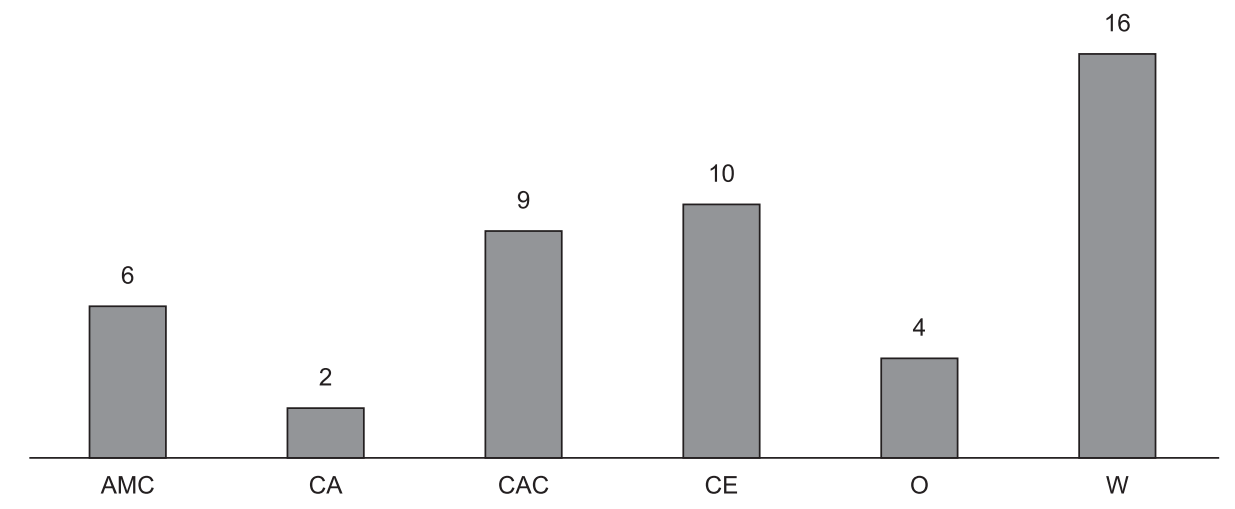

Figure 3. Amphibians Distributional Pattern in the state of Piauí: AMC = species that occur both in Amazon Rain Forest and Cerrado biomes; CA = species that occur only in Caatinga biome; $\mathrm{CAC}=$ species that occur both in Caatinga and Cerrado biomes; $\mathrm{CE}=$ species endemic to Cerrado biome; $\mathrm{O}=$ species that occur in open domains; $\mathrm{W}=$ widespread species.

Pristimantis fenestratus (Steindachner, 1864) for Piauí. However, neither references nor voucher specimens are provided in order to confirm species identification. Among species mentioned by Freitas (2011), we consider that Leptodactylus sp. is the same species here presented as Adenomera sp. (aff. andreae) (see Table 1), an undescribed species broadly distributed in Piauí. We considered that because we also consider the record of a species of Pristimantis for the state, once that Freitas (2011) provided a photograph of a specimen of Pristimantis from Gurgueia region. Additionally, it is known that a species from this genus occurs in the frontier with Maranhão and Piauí (R.W. Ávila, personal communication). However, considering the available information is weakly supported to confirm identification at the species level, we opted to assign the name Pristimantis gr. conspicillatus to the species that occurs in the Cerrado of southern Piauí. The presence of $L$. labyrinthicus, $L$. caatingae and Physalameus marmoratus for Piauí still need further evidence in order to confirming the presence of these species in state. For that reason, we preferred to exclude these records in the present study.

The state of Piauí does not have any endemic species detected so far; however, its localization between the Caatinga in the east and the Cerrado in the west shows endemic species for both biomes. For instance, Rhinella veredas, $R$. cerradensis, R. rubescens, Eupemphix nattereri, Physalaemus centralis, and Phyllomeduza azurea occur in savannas areas from Uruçuí and Ribeiro Gonçalves municipalities (Brandão et al. 2007, Maciel et al. 2007, present study), being considered species typical from Cerrado. In contrast, Rhinella mirandaribeiroi, Dendropsophus rubicundulus, Proceratophrys goyana, Leptodactylus pustulatus have wider distribution in the state, occurring in Cerrado areas but also in coastal zone and ecotonal areas of Caatinga and Cerrado (see Silva et al. 2007, Loebmann \& Mai 2008, Loebmann et al. 2010b, Narvaes \& Rodrigues 2009). For the Caatinga endemics, Rhinella jimi occurs in the north of the state in the coastal zone (Silva et al. 2007, Loebmann \& Mai 2008) and in the Caatinga areas of Caxingó municipality, while Ceratophrys joazeirensis was reported in the municipality of São Raimundo Nonato.

Species with influence of the Amazon Rainforest such as Hypsiboas boans, Osteocephalus taurinus, Sphaenorhyncus lacteus, Proceratophrys concavitympanum, Leptodactylus hylaedactylus and Lithobates palmipes are found in ecotone areas on the border with Maranhão state, suggesting a possible dispersal route for these species. The low level of endemism confirms the earlier studies of Nogueira et al. (2009) for lizards and Valdujo et al. (2012) for amphibians, however we believe that new inventories, especially at the border of the states of Tocantins and Maranhão on the southwestern region, can substantially increase the diversity in Piauí. Those region encompass one of richest amphibian diversity areas in Cerrado, and are considered priority areas for conservation (Diniz-Filho et al. 2005). Undescribed species such as Adenomera sp. (aff. andreae) (A. Fouquet, unpublished data) reinforce the need for conserving these areas to protect these species.

The lack of endangered species in the state, and only two 'data deficient' species, Rhinella cerradensis and Proceratophrys concavitympanum, does not minimize the importance of conservation of the pristine habitats, especially due to the increased deforestation rate that occurs in Piauí, for soy and eucalyptus cultures.

Strict protection conservation units are well represented in the state of Piauí: Estação Ecológica de Uruçui-Una, Parque Nacional da Serra da Capivara, Parque Nacional da Serra das Confusões, Parque Nacional de Sete Cidades, and Parque Nacional das Nascentes do Parnaíba, however, inventories in some of these areas are available only in gray literature, like Management Plans. Knowledge about species diversity and composition is mandatory for the functionality and effectiveness of a protected area and to access the efficacy of the protected area in conserving these species (Rylands \& Brandon 2005). Strict protection conservation units, such as national parks and ecological stations aim to conserve biodiversity and promoting scientific research. Research should be encouraged by the policy makers and the scientific community, following the examples of Uetanabaro et al. (2007) and Valdujo et al. (2011).We hope that in the near future new articles related to these topics will strengthen the conservation of these regions and, consequently, the biodiversity present in those areas.

\section{Acknowledgements}

We thank João A. de Araújo Filho, José Guilherme G. de Sousa and Diego A. Teles for field assistance. Anne Taffin D'Heursel Baldisseri for English review. Robson W. Ávila for providing personal data for sampled localities in Piauí. Igor J. Roberto thanks Funcap for the Masters Degree fellowship. D.L. thanks CNPq (Proc. 140226/2006-0) and CAPES (Proc. 338632/2010) for Doctoral and Post-doctoral fellowships, respectively. Samuel C. Ribeiro thanks CNPQ for the Doctoral Degree scholarship. 


\section{References}

ANDRADE, E.B., GUIMARÃES, R., LEITE JUNIOR, J.M.A. \& LEITE, J.R.S.A. 2011. Amphibia, Anura, Leptodactylidae, Leptodactylus syphax Bokermann, 1969: Distribution extension and geographic distribution map. Check List 7(5):592-593.

ANNUNZIATA, B.B., FONTENELE, W.N., CASTRO, I.S., GURGEL, R.F. \& NASCIMENTO, K.A. 2007. Amphibia, Anura, Hylidae, Dendropsophus rubicundulus: Distribution extension. Check List 3(3):242-243.

ANNUNZIATA, B.B., CASTRO, I.S. \& FONTENELE, W.N. 2009. Scinax fuscomarginatus (Brown-bordered Snouted Tree-frog). Herpetol. Rev. 40(1):110.

ÁVILA, R.W., KAWASHITA-RIBEIRO, R.A. \& MORAIS, D.H. 2011. A new species of Proceratophrys (Anura: Cycloramphidae) from western Brazil. Zootaxa 2890:20-28.

BENÍCIO, R.A., SILVA, G.R. \& FONSECA, M.G. 2011. Amphibia, Anura, Hylidae, Sphaenorhynchus lacteus (Daudin, 1800): First record of the genus and species for the state of Piauí, Brazil. Check List 7(2):196-197.

BENÍCIO, R.A., SILVA, G.R. \& FONSECA, M.G. 2012. Physalaemus cicada Bokermann, 1966 (Anura: Leiuperidae): Distribution extension. Check List 8(4):630-631.

BRANDÃO, R.A., MACIEL, N.M. \& SEBBEN, A. 2007. A new species of Chaunus from Central Brazil. (Anura: Bufonidae). J. Herpetol. 41:309316. http://dx.doi.org/10.1670/0022-1511(2007)41[309:ANSOCF]2.0 .CO;2

CARAMASCHI, U. \& JIM, J. 1983a. Uma nova espécie de Hyla do grupo marmorata do nordeste Brasileiro (Amphibia, Anura, Hylidae). Rev. Bras. Biol. 43:195-198.

CARAMASCHI, U. \& JIM, J. 1983b. A new microhylid frog, genus Elachistocleis (Amphibia, Anura) from northeastern Brazil. Herpetol. 39:390-394.

CARAMASCHI, U. 2006. Redefinição do grupo de Phyllomedusa hypochondrialis, com redescrição de P. megacephala (MirandaRibeiro, 1926), revalidação de $P$. azurea Cope, 1862 e descrição de uma nova espécie (Amphibia, Anura, Hylidae). Arq. Mus. Nac., Rio de Janeiro. 64:159-179.

CARAMASCHI, U. 2008. Taxonomic status of Leptodactylus ochraceus (Anura: Leptodactylidae): a forgotten species. Rev. Bras. Zool. 25(3):523-528. http://dx.doi.org/10.1590/S0101-81752008000300020

CARDOSO, A.J. \& HEYER, W.R. 2005. Advertisement, aggressive, and possible seismic signals of the frog Leptodactylus syphax (Amphibia, Leptodactylidae). Alytes 13:67-76.

CARNAVAL, A.C., HICKERSON, M.J., HADDAD, C.F.B., RODRIGUES, M.T. \& MORITZ, C. 2009. Stability predicts genetic diversity in the Brazilian Atlantic forest hotspot. Science 323:785-789. http://dx.doi. org/10.1126/science.1166955

DINIZ-FILHO, J.A.F., BINI, L.M., BASTOS, R.P., VIEIRA, C.M. \& VIEIRA, L.C.G. 2005. Priority areas for amphibian conservation using biogeographical data: a comparison of greedy, rarity and simulated annealing algorithms to define reserve networks in Cerrado. Braz. J. Biol. 65(2):251-261. http://dx.doi.org/10.1590/S151969842005000200008

FIGUEIREDO, W.M.B., SILVA, J.M.C. \& SOUZA, M.A. 2006. Biogeografia e a Conservação da Biodiversidade. In Biologia da Conservação: Essências (C.F.D. Rocha, H.G. Bergallo, M. Van Sluys \& M.A.S. Alves eds.). RiMA, São Carlos, p.135-156.

FREITAS, M.A. 2011. Anfíbios do Nordeste Brasileiro. Produção do Autor.

FROST, D.R. 2013. Amphibian species of the world: an online Reference. version 5.6 (9 January, 2013). American Museum of Natural History, New York. http://research.amnh.org/vz/herpetology/amphibia/ (último acesso em 02/02/2013)
HEYER, W.R. 1978. Systematics of the fuscus group of the frog genus Leptodactylus (Amphibia, Leptodactylidae). Nat. Hist. L. A. Count. Sci. Bull. 29:1-85.

HEYER, W.R. 1994. Variation within the Leptodactylus podicipinus-wagneri complex of frogs (Amphibia, Leptodactylidae). SM. C. Zool. 546:1-124.

HEYER, W.R. 2005. Variation and taxonomic clarification of the large species of the Leptodactylus pentadactylus species group (Amphibia, Leptodactylidae) from Middle America, northern South America and Amazonia. Arq. Zool. 37(3): 269-348.

INTERNATIONAL UNION FOR CONSERVATION OF NATURE - IUCN. 2012. The IUCN Red List of Threatened Species. version 2012.2. http:// www.iucnredlist.org. (último acesso em 17/10/ 2012).

LEITE JUNIOR, J.M.A., SAMPAIO, J.M.S., SILVA-LEITE, R.S., TOLEDO, L.F., LOEBMANN, D. \& LEITE, J.R.S.A. 2008. Amphibia, Anura, Hylidae, Scinax fuscomarginatus: Distribution extension. Check List 4(4):475-477.

LISBOA, B.S., SILVA, U.G. \& HADDAD, C.F.B. 2010. Amphibia, Anura, Cycloramphidae, Odontophrynus carvalhoi Savage and Cei, 1965: Distribution extension. Check List 6(4):493-494.

LOEBMANN, D. \& HADDAD, C.F.B. 2010. Amphibians and reptiles from a highly diverse area of the Caatinga domain: composition and conservation implications. Biota Neotrop. 10: http://www. biotaneotropica.org.br/v10n3/en/abstract?article+bn03910032010 (último acesso em 02/06/2012).

LOEBMANN, D. \& MAI, A.C.G. 2008. Amphibia, Anura, Coastal Zone, state of Piauí, Northeastern Brazil. Check List 4(2):161-170.

LOEBMANN, D., MAI, A.C.G. \& LEE, J.T. 2010a. The invasion of five alien species in the Delta do Parnaíba Environmental Protection Area, Northeastern Brazil. Rev. Biol. Trop. 58:909-923.

LOEBMANN, D., ORRICO, V.G.D., CASSINI, C. \& GIASSON, L.O.M. 2010b. Anfíbios. In (MAI, A.C.G. \& D. Loebmann, eds.). Guia Ilustrado: Biodiversidade do Litoral do Piauí. Sorocaba: Gráfica e Editora Paratodos, p.182-211.

MACIEL, N.M., BRANDÃO, R.A., CAMPOS, L.A. \& SEBBEN, A. 2007. A large new species of Rhinella (Anura: Bufonidae) from Cerrado of Brazil. Zootaxa 1627:23:39.

NAPOLI, F.M. \& CARAMASCHI, U. 1999. Geographic variation of Hyla rubicundula and Hyla anataliasiasi, with the description of a new species (Anura, Hylidae). Alytes 16(3):165-189.

NARVAES, P. \& RODRIGUES, M.T. 2009. Taxonomic revision of Rhinella granulosa species group (Amphibia, Anura, Bufonidae), with a description of a new species. Arq. Zool. 40:1-73.

NOGUEIRA, C., COLLI, G.R. \& MARTINS, M. 2009. Local richness and distribution of the lizard fauna in natural habitat mosaics of the Brazilian Cerrado. Austral Ecol. 34:83-96. http://dx.doi.org/10.1111/j.14429993.2008.01887.x

RAMALHO, W.P., VIANA, F., BENEVIDES, R., SILVA, E.P. \& ALVESSILVA, R. 2011. First Record of Lithobates palmipes (Spix, 1824) (Anura, Ranidae) for the State of Piauí, Northeastern Brazil. Herpetol. Notes. 4:249-251.

ROBERTO, I.J., CARDOZO, D. \& ÁVILA, R.W. 2013. A new species of Pseudopaludicola (Anura, Leiuperidae) from western Piauí State, northeast Brazil. Zootaxa 3636(2):348-36.

RYLANDS, A.B. \& BRANDON, K. 2005. Brazilian Protected Areas. Conserv. Biol. 19:612-618. http://dx.doi.org/10.1111/j.1523-1739.2005.00711.x

SEGALLA, M.V., CARAMASCHI, U., CRUZ, C.A.G., GARCIA, P.C.A., GRANT, T., HADDAD, C.F.B. \& LANGONE, J. 2012. Brazilian amphibians - List of species. Sociedade Brasileira de Herpetologia. http:// www.sbherpetologia.org.br (último acesso em 02/06/2012).

SILVA, G.R., SANTOS, C.L., ALVES, M.R., SOUZA, S.D.V. \& ANNUNZIATA, B.B. 2007. Anfíbios das dunas litorâneas do extremo norte do Estado do Piauí, Brasil. Sitientibus 7(4):334-340. 
SILVANO, D.L. \& SEGALLA, M. 2005. Conservação de anfíbios no Brasil. Megadiversidade 1(1):79-86.

STEVAUX, M.N. 2002. A new species of Bufo Laurenti (Anura, Bufonidae) from northeastern Brazil. Rev. Bras. Zool. 19:235-242. http://dx.doi. org/10.1590/S0101-81752002000500018

STUART, S.N., CHANSON, J.S., COX, N.A., YOUNG, B.E., RODRIGUES, A.S.L., FISCHMAN, D.L. \& WALLER, R.W. 2004. Status and trends of amphibian declines and extinctions worldwide. Science 306(5702):1783-1786. http://dx.doi.org/10.1126/science.1103538

UETANABARO, M., SOUZA, F.L., LANDGREF-FILHO, P., BEDA, A.F. \& BRANDÃO, R.A. 2007. Anfíbios e répteis do Parque Nacional da Serra da Bodoquena, Mato Grosso do Sul, Brasil. Biota Neotropica 7(3): http:// www.biotaneotropica.org.br/v7n3/pt/abstract?inventory+bn01207032007 (último acesso em 20/04/2012).
VALDUJO, P.H., CAMACHO, A., RECORDER, R., TEIXEIRA JUNIOR, M., GUELLERE, J.M., MOTT, T., NUNES, P.M.S. \& RODRIGUES, M.T. 2011. Anfíbios da Estação Ecológica Serra Geral do Tocantins, região do Jalapão, estados do Tocantins e Bahia. Biota Neotrop. 11(1): http:// www.biotaneotropica.org.br/v11n1/pt/abstract?article+bn03511012011 (último acesso em 03/06/2012).

VALDUJO, P.H., SILVANO, D.L., COLLI, G. \& MARTINS, M. 2012. Anuran species composition and distribution patterns in Brazilian Cerrado, a Neotropical Hotspot. S. Am. J. Herpetol. 7(2):63-78. http://dx.doi. org/10.2994/057.007.0209

YOUNG, B.E., LIPS, K.R., REASER, J.K., IBÃNEZ, R., SALAS, A.W., CEDEÑO, J.R., COLOMA, S.R., RON, S.R., LA MARCA, E., MEYER, J.R., MUÑOZ, A., BOLAÑOS, F., CHAVES, G. \& ROMO, D. 2001. Population declines and priorities for amphibian conservation in Latin America. Conserv. Biol. 15:1213-1223. http://dx.doi.org/10.1046/j.15231739.2001.00218.x 


\section{Appendix}

Appendix 1.

Ceratophrys joazeirensis - ZUEC-AMP 9141; Corythomantis greeningi - URCA 2344; Dendropsophus minusculus - UFPB 4518; Dendropsophus minutus - URCA 2339; Dendropsophus nanus - URCA 234; Dendropsophus rubicundulus - URCA 2356; Dendropsophus soaresi - URCA 2340; Dermatonotus muelleri - URCA 2366; Elachistocleis piauiensis - MNRJ 66848; Eupemphix nattereri - URCA 2354; Hypsiboas boans - MNRJ 71656; Hypsiboas multifasciatus - URCA 2194; Hypsiboas punctatus - URCA 2225; Hypsiboas raniceps - UFPB 4522; Adenomera sp. (aff. andreae) - URCA 2229; Leptodactylus macrosternum - URCA 2193; Leptodactylus fuscus - URCA 2364; Leptodactylus podicipinus - MZUSP 25015; Leptodactylus pustulatus - UESPI 38; Leptodactylus syphax-ZUEC-AMP 8829; Leptodactylus troglodytes - URCA 2346; Leptodactylus vastus - UFPB 4524; Lithobates palmipes - CH-UFRRJ/ RU7278; Osteocephalus taurinus - URCA 2334; Phyllomedusa azurea - URCA 2353; Phyllomedusa nordestina - UFPB 4525; Physalaemus albifrons - CFBH 18322; Physalaemus centralis - URCA 2359; Physalaemus cuvieri-URCA 2198; Pleurodema diplolister - MNRJ 50381; Proceratophrys cf. caramaschii - UFPB 4529; Proceratophrys concavitympanum - URCA 2358; Pseudopaludicola parnaiba - URCA 2158; Pseudopaludicola mystacalis - URCA 2367; Rhinella granulosa - UFPB 4515; Rhinella jimi - UFPB 4517; Rhinella mirandaribeiroi - URCA 2345; Rhinella schneideri - URCA 2368; Rhinella veredas - MNRJ 39050; Scinax fuscomarginatus - URCA 2200; Scinax fuscovarius - URCA 2329; Scinax nebulosus - URCA 2224; Scinax x-signatus - UFPB 4532; Trachycephalus typhonius - URCA 2235. 